\title{
Kedudukan dan Kekuatan Pembuktian Alat Bukti Elektronik dalam Hukum Acara Perdata Indonesia
}

\author{
Trio Yusandy \\ Fakultas Hukum Universitas Muhammadiyah Aceh \\ trioyusandy@yahoo.co.id \\ DOI : 10.32672/jsa.v7i5.1522
}

\begin{abstract}
ABSTRAK
Alat bukti adalah segala sesuatu yang dapat dipakai untuk membuktikan. Dalam hukum acara perdata yang didasarkan oleh Pasal 164 HIR dan 284 Rbg serta Pasal 1886 KUHPerdata. Dengan adanya keterbukaan dan kebebasan dalam berbagai bidang kehidupan dibidang Ilmu Pengetahuan dan Teknologi yang berdampak pada budaya lokal dan pasar global. Seandainya terjadi sengketa dalam transaksi pembayaran, maka pembuktian harus sesuai dengan apa yang dinyatakan oleh undang-undang, dan dalam pelaksanaannya undang-undang di Indonesia masih tertinggal dan belum dapat menjangkau perkembangannya. Kedudukan alat bukti elektronik dalam Hukum yang ada di Indonesia sah, juga kekuatan alat bukti elektronik dipersamakan dengan dokumen yang dibuat diatas kertas, kemudian faktor yang menghambat kekuatan alat bukti elektronik dikarenakan adanya hambatan substansi Undang-undang Informasi dan Transaksi Elektronik, hambatan diluar Undang-undang, sosial budaya, teknologi dan pembuktian dipersidangan, serta upaya yang dapat menguatkan alat bukti yaitu menampilkan dokumen elektronik secara utuh, dapat menjamin keasliannya, dilengkapi petunjuk umum dan memiliki mekanisme berkelanjutan.
\end{abstract}

Kata kunci: alat bukti, elektronik, perdata

\section{PENDAHULUAN}

Pembuktian adalah tahap yang memiliki peranan penting bagi hakim untuk menjatuhkan putusan. Proses pembuktian dalam proses persidangan dapat dikatakan sebagai sentral dari prosespemeriksaan di pengadilan. Pembuktian menjadisentral karena dalil-dalil para pihak diuji melalui tahap pembuktian guna menemukan hukum yang akan diterapkan (rechtoepasing) maupun yang ditemukan (rechtvinding) dalam suatu perkara tertentu. Hal ini sesuai dengan yang dikemukakan Achmad Ali (2009:17) dalam buku Menguak Teori Hukum (Legal Theory) dan Teori Peradilan (Judicialprudence).

Pembuktian bersifat historis yang artinya pembuktian inimencoba menerapkan peristiwaapa yang telah terjadi dimasa lampau yang pada saat ini dianggap sebagai suatu kebenaran, peristiwa yang harus dibuktikanadalahperistiwa yang relevan, karena peristiwa yangirrelevantidak perlu dibuktikan .pada intinya yang harus dibuktikandalam tahap pembuktian ini adalah peristiwa-peristiwa yang menuju pada kebenaran yang relevan menurut hukum.

Achmad Ali dan Wiwie Heryani (2013:20) dalam buku Asas-asas Hukum Pembuktian Perdata menyatakan tujuan pembuktian adalah untuk menetapkan hubungan 
hukum antara kedua belah pihak yang berpekara dipengadilan untuk dapat memberi kepastian dan keyakinan kepada hakim atas dalil yang disertai alat bukti yang diajukan dipengadilan, pada tahap ini hakim dapat mempertimbangkan putusan perkara yang dapat memberikan suatu kebenaran yang memiliki nilai kepastian hukum dan keadilan.Sistem hukum pembuktian yang dianut di Indonesia adalah sistem tertutup dan terbatas dimana para pihak tidak bebas mengajukan jenis atau bentuk alat bukti dalam proses penyelesaian perkara. Undang-undang telah menentukan secara tegas apa saja yang sah dan bernilai sebagai alat bukti sesuai yang dikemukakan Soerjono Soekanto (2014:38), Pengantar Penelitian Hukum. Pembatasan kebebasan juga berlaku bagi hakim dimana hakim tidak bebas dan leluasa menerima apa aja yang diajukan para pihak sebagai alat bukti.Apabila para pihak yang berpekara mengajukan alat bukti diluar ketentuan yang ada didalam undang-undang yang mengatur, hakim harus menolak dan mengesampingkan dalam penyelesaian perkara.

Dalam Pasal 1866 Kitab Undang-Undang Hukum Perdata, Rechts Reglement Buitengwesten (RBg) Pasal 284, pasal 164 Het Herziene Indonesisch Reglement $(H I R)$ menerangkan lima alat bukti yang digunakan dalam perkara perdata yaitu Alat bukti tertulis, Alat bukti saksi, Alat bukti berupa persangkaan-persangkaan, Alat bukti berupa pengakuan, dan alat bukti sumpah.

Apabila dilihat pada ketentuan dalam Kitab Undang-Undang Hukum Perdata tentang alat bukti, kemungkinan digital signature yang digunakan sebagai alat bukti, tidak mungkin atau ditolak baik oleh hakim mau pun pihak lawan. Hal ini dikarenakan ternyata pembuktian yang dikehendaki berdasarkan ada ketentuan perundang-undangan, mensyaratkan bahwa alat bukti berupa tulisan, sedangkan digital signature bersifat tanpa kertas bahkan merupakan scriplees transaction, Achmad Ali dan Wiwie Heryani (2013:21).

Pada perkembanganya dikenal pula alat bukti elektronik yang diatur dalam Undang-Undang No. 11 Tahun 2008 jo Undang-Undang No. 19 Tahun 2016 tentang Informasi dan Transaksi Elektronik (ITE) yang memuat SMS atau Email yang dijadikan sebagaialatbukti di persidangan. Terkait dengan pandangan perubahan terhadap hukum, para ahli hukum sepakat bahwa hukum harus dinamis, tidak boleh statis dan harus tetap mengayomi masyarakat. Ada dua pandangan yang sangat dominan terkait dengan perubahan hukum dalam kehidupan masyarakat, yakni pandangan tradisional dan modern.

Menurut pandangan, hukum hanyalah sebagai pembenar atas perubahan yang terjadi di dalam masyarakat. Sementara itu, pandangan modern menyatakan bahwa hukum diusahakan agar dapat menampung segala perkembangan baru. Oleh karena itu, hukum harus selalu bersamaan muncul dengan adanya perubahan dan peristiwa yang terjadi, Achmad Ali dan Wiwie Heryan (2013:27).

Berdasarkan uraian pada latar belakang, maka yang menjadi pokok permasalahan dalam penelitian ini adalah sebagai berikut:

1. Bagaimanakah kedudukan dan kekuatan alat bukti elektronik dalam sistem pembuktian perkara perdata di Indonesia?

2. Faktor-faktor apa sajakah yang menghambat kekuatan alat bukti elektronik dalam sistem pembuktian perkara perdata di Indonesia? 
3. Upaya apa sajakah yang dapat dilakukan dalam menguatkan kekuatan alat bukti elektronik dalam sistem pembuktian perkara perdata di Indonesia?

\section{METODE PENELITIAN}

Jenis penelitian hukum yang digunakan dalam penelitian ini adalah penelitian hukum normatif yang berfokus pada norma hukum positif yang mengatur tentang alat-alat bukti dalam Hukum AcaraPerdata Indonesia. Pendekatan penelitian yang akan dilakukan oadalah pendekatan undang-undang dan kasus, yaitu pendekatan yang dilakukan berdasarkan bahan hukum utama dengan cara menelaaht eori-teori, konsep-konsep, asasasas hukum serta peraturan perundang-undangan yang berhubungan dengan penelitian.

\section{PEMBAHASAN}

\section{Kedudukan dan Kekuatan Alat Bukti Elektronik Kedudukan Alat Bukti Elektronik}

Mengenai alat bukti yang diatur secara limitatif atau bersifat terbatas dalam proses pembuktian perdata mengakibatkan transkrip elektronik secara utuh dan penuh, belum dapat diterima sebagai alat bukti di pengadilan. Sebagai contoh, dalam transaksi jual beli melalui internet menempatkan konsumen dalam posisi tawar yang lemah. Hal ini dapat dilihat bahwa informasi mengenai keadaan suatu barang tertentu sepenuhnya dibuat secara sepihak oleh pelaku usaha.

Posisi konsumen dalam transaksi jual beli melalui internet tidak memberikan peluang kepada konsumen untuk melihat, mengidentifikasi dan menyentuh barang secara langsung, karena sifat dari transaksi yang dilakukan tanpa melalui tatap muka secara langsung.

Kedudukan alat bukti elektronik dalam perkara perdata saat ini, dipandang tidak lagi harus berpatokan terhadap jenis alat bukti yang secara limitatif telah ditentukan oleh aturan perundangan. Pola dan tingkah laku kehidupan manusia yang semakin berkembang, turut mempengaruhi aspek dalam lalu lintas hubungan keperdataan yang berlangsung hingga saat ini. Kehadiran Undang-undang Nomor 11 Tahun 2008 jo Undang-undang Nomor 19 Tahun 2016 Tentang Informasi dan Transaksi Elektronik (ITE) sebagai bentuk penegasan diakuinya transaksi elektronik dalam lalu lintas hubungan keperdataan, serta dapat dipergunakannya transkrip elektronik sebagai bentuk alat bukti dipengadilan memberikan pengaruh yang cukup besar terhadap perkembangan hubungan keperdataan yang berlangsung saat ini.

Pengakuan terhadap kedudukan alat bukti elektronik dalam proses pembuktian perkara perdata, tidak hanya sebatas mengenai aspek pengakuan secara legalitas. Proses pembuktian dalam perkara pidana maupun perdata merupakan salah satu unsur penting, sehingga dengan adanya pengakuan mengenai kedudukan/eksistensi alat bukti elektronik tersebut, dapat menjamin pelindungan dan kepastian hukum diantara para pihak.

Pengertian Informasi Elektronik dalam ketentuan umum Pasal 1 Undang-undang Nomor 11 Tahun 2008 disebutkan sebagai satu atau sekumpulan data elektronik, termasuk tetapi tidak terbatas pada tulisan, suara, gambar, peta, rancangan, foto, electronic data interchange (EDI), surat elektronik (electronic mail), telegram, teleks, telecopy atau 
sejenisnya, huruf, tanda, angka, kode akses, simbol, atau perforasi yang telah diolah yang memiliki arti atau dapat dipahami oleh orang yang mampu memahaminya.

Dalam Pasal 1 ayat (4) Undang-undang Nomor 11 Tahun 2008 jo Undang-undang Nomor 19 Tahun 2016, dokumen elektronik adalah setiap informasi elektronik, yang dibuat, dikirimkan, diterima, atau disimpan dalam bentuk analog, digital, elektromagnetik, optikal, atau sejenisnya yang dapat dilihat, ditampilkan, dan/atau didengar melalui komputer atau sistem elektronik, termasuk tetapi tidak terbatas pada tulisan, gambar, peta, rancangan, foto atau sejenisnya, huruf, tanda, angka, kode akses, simbol atau perforasi yang memiliki makna atau arti yang dapat dipahami oleh orang yang mampu memahaminya.

Karakteristik dokumen elektronik yang dapat dialihkan atau disimpan dalam beberapa bentuk, memungkinkan dokumen elektronik dalam praktik perkara di persidangan tidak ditemui dalam satu bentuk media yang baku, hal tersebut dapat dilakukan mengingat sifat dari informasi elektronik dan/atau dokumen elektronik dapat dialihkan ke dalam beberapa bentuk media yang lain.

Kedudukan alat bukti elektronik seperti, transaksi elektronik masih terus dipertanyakan oleh sebagian pihak. Salah satu kasus terjadi pada seorang mahasiswa dari Yogyakarta mengalami penipuan secara online. Korban mengaku ditipu seseorang yang mengaku menjual leptop. Kejadian berawal ketika korban melakukan pencarian barang di dunia maya dan menemukan kontak terduga pelaku, dilanjutkan dengan saling tukar kontak dan tawar menawar.

Menurut Hj. Efa Laela Fakhriah jenis alat bukti yang dapat dikategorikan sebagai alat bukti elektronik yakni a). Foto dan hasil rekaman, b). Hasil print out dari mesin Faximili, c). Microfilm, d). Email/Surat Elektronik, e). Video teleconference, dan e) Tandatangan Elektronik

Ketentuan mengenai alat bukti elektronik secara sah sebagai alat bukti dalam hukum, diakui dalam Pasal 5 ayat (2) yang menyatakan informasi Elektronik dan/atau Dokumen Elektronik dan atau hasil cetaknya sebagaimana dimaksud pada ayat (1) merupakan perluasan alat bukti yang sah sesuai dengan hukum acara yang berlaku di Indonesia. Informasi elektronik dan/atau dokumen elektronik sebagai perluasan alat bukti di pengadilan, berdasarkan Pasal 5 ayat (2) dapat dikatakan sebagai alat bukti elektronik.

Dalam ketentuan Pasal 6 Undang-undang Nomor 11 tahun 2008 tentang Informasi dan Transaksi Elekronik (ITE) yang berbunyi dalam hal terdapat ketentuan lain selain yang diatur dalam Pasal 5 ayat (4) yang mensyaratkan suatu informasi harus berbentuk tertulis atau asli, informasi elektronik dan/atau dokumen elektronik dianggap sah sepanjang informasi yang tercantum di dalamnya dapat diakses, ditampilkan, dijamin keutuhannya, dan dapat dipertanggungjawabkan sehingga menerangkan suatu keadaan.

Dari ketentuan Pasal 6 tersebut, selama bentuk tertulis identik dengan informasi dan/atau dokumen yang tertuang di atas kertas semata, padahal pada hakikatnya informasi dan/atau dokumen elektronik dapat dituangkan ke dalam media apa saja, termasuk media elektronik. Dalam lingkup sistem elektronik informasi yang asli dengan salinannya tidak relevan lagi untuk dibedakan sebab sistem elektronik pada dasarnya beroperasi dengan cara penggandaan yang mengakibatkan informasi yang asli tidak dapat dibedakan lagi dari salinannya. 
Hal ini berarti bahwa prinsip penggandaan elektronik seolah-olah menampilkan hasil salinan yang tidak dapat dibedakan dengan aslinya. Mengenai hal ini, berdasarkan penjelasan Pasal 6 di atas menyatakan bahwa sistem elektronik informasi yang asli tidak relevan lagi untuk dibedakan, menurut hemat penulis hal yang demikian harus tetap ada pembedaan antara salinan/kutipan disatu sisi, dan dokumen asli pada sisi lainnya, meskipun prinsip penggandaan yang dilakukan melalui media elektronik seolah-olah menampilkan hasil yang asli.

\section{Kekuatan Alat Bukti Elektronik}

Penggunaan alat bukti elektronik secara sah diakui dengan adanya Undangundang Nomor 11 tahun 2008 jo Undang-undang Nomor 19 Tahun 2016 tentang Informasi dan Transaksi Elektronik (ITE) pada Pasal 5 ayat (2).

Permasalahan mengenai kekuatan pembuktian yang melekat pada alat bukti elektronik selanjutnya dapat dilihat dalam penjelasan umum Undang-undang Nomor 11 Tahun 2008 jo Undang-undang Nomor 19 Tahun 2016 tentang Informasi dan Transaksi Elektronik (ITE). Penjelasan umum undang-undang tersebut menyatakan bahwa ;

"Dalam kegiatan e-commerce antara lain dikenal adanya dokumen elektronik yang kedudukannya disetarakan dengan dokumen yang dibuat di atas kertas".

Kekuatan pembuktian yang melekat pada alat bukti elektronik, oleh Undangundang Nomor 11 Tahun 2008 jo Undang-undang Nomor 19 Tahun 2016 tentang Informasi dan Transaksi Elektronik (ITE) yang menyatakan bahwa dokumen elektronik disetarakan dengan dokumen yang dibuat di atas kertas. Hal ini, berarti bahwa kekuatan pembuktian dokumen elektronik dalam praktik perkara perdata dipersamakan dengan kekuatan alat bukti tulisan (surat).

Kedudukan salinan suatu dokumen elektronik menurut penjelasan umum Pasal 6 Undang-undang Nomor 11 Tahun 2008 tentang Informasi dan Transaksi Elektronik (ITE) menyatakan prinsip penggandaan sistem elektronik mengakibatkan informasi yang asli tidak dapat dibedakan dengan salinannya, sehingga hal tersebut tidak relevan lagi untuk dibedakan. Mengenai hal tersebut, dapat dilihat penjelasan Pasal 6 Undang-undang Nomor 11 Tahun 2008 tentang Informasi dan Transaksi Elektronik (ITE) yang berbunyi sebagai berikut;

"Selama ini bentuk tertulis identik dengan informasi dan/atau dokumen yang tertuang di atas kertas semata, padahal pada hakikatnya informasi dan/atau dokumen elektronik dapat dituangkan ke dalam media apa saja, termasuk media elektronik. Dalam lingkup sistem elektronik informasi yang asli dengan salinannya tidak relevan lagi untuk dibedakan sebab sistem elektronik pada dasarnya beroperasi dengan cara penggandaan yang mengakibatkan informasi yang asli tidak dapat dibedakan lagi dari salinannya".

Mengenai kekuatan pembuktian yang melekat terhadap sebuah tanda tangan elektronik, dapat dilihat dalm ketentuan Pasal 11 Undang-undang Informasi dan Transaksi Elektronik (ITE) yang berbunyi tanda tangan elektronik memiliki kekuatan hukum dan akibat hukum yang sah selama memenuhi persyaratan sebagai berikut;

a. Data pembuatan tanda tangan elektronik terkait hanya kepada penanda tangan. 
b. Data pembuatan tanda tangan elektronik pada saat proses hanya berada dalam kuasa penandatangan.

c. Segala perubahan terhadap tanda tangan elektronik yang terjadi setelah waktu penandatanganan dapat diketahui.

d. Segala perubahan terhadap informasi elektronik yang terkait dengan tanda tangan elektronik tersebut setelah waktu penandatanganan dapat diketahui.

e. Terdapat cara tertentu yang dipakai untuk mengidentifikasi siapa penandatangannya.

f. Terdapat cara tertentu untuk menunjukkan bahwa penandatangan telah memberikan persetujuan terhadap informasi elektronik yang terkait.

Keterikatan para pihak dalam suatu urusan penandatanganan, berlaku sepanjang kesepakatan tersebut tidak menyalahi ketentuan pokok hukum perikatan yang terdapat dalam Pasal 1320 KUH Perdata, atau belum mencapai batas waktu yang telah diperjanjikan, hal ini berlaku dalam hubungan suatu kontak. Mengenai adanya sejumlah persyaratan yang menyatakan kekuatan pembuktian tanda tangan elektronik seperti di atas, sebagaimana disebut dalam penjelasan Pasal 11 Undang-undang Nomor 11 tahun 2008 jo Undang-undang Nomor 19 Tahun 2016 tentang Informasi dan Transaksi Elektronik (ITE) merupakan syarat minimum yang harus dipenuhi dalam setiap tanda tangan elektronik.

\section{Faktor-Faktor Penghambat Kekuatan Alat Bukti Elektronik}

Pengakuan Mahkamah Agung terhadap dokumen elektronik pada sistem peradilan pertama kali diketahui melalui Surat Edaran Mahkamah Agung (SEMA) Nomor 14 Tahun 2010 tentang Dokumen Elektronik sebagai Kelengkapan Permohonan Kasasi dan Peninjauan Kembali. SEMA ini bertujuan untuk meningkatkan efisiensi dan efektivitas proses minutasi berkas perkara serta menunjang pelaksanaan transparansi dan akuntabilitas serta pelayanan publik pada Mahkamah Agung dan Badan Peradilan di bawahnya. Namun SEMA ini tidaklah mengatur tentang dokumen elektronik sebagai alat bukti melainkan dokumen elektronik berupa putusan maupun dakwaan yang dimasukkan pada compact disc, flash disk/dikirim melalui email sebagai kelengkapan permohonan kasasi dan peninjauan kembali.

SEMA ini telah mengalami perubahan berdasarkan SEMA 1 Tahun 2014 tentang Perubahan atas SEMA 14 Tahun 2010 tentang Dokumen Elektronik sebagai kelengkapan Permohonan Kasasi dan Peninjauan Kembali. Perubahan SEMA ini dilakukan berkaitan dengan sistem pemeriksaan berkas dari sistem bergiliran menjadi sistem baca bersama yang diarahkan secara elektronik. Dalam butir-butir SEMA terdapat penambahan detail dokumen-dokumen yang wajib diserahkan para pihak berperkara secara elektronik tapi sekali lagi kepentingannya bukan dalam kaitannya sebagai alat bukti elektronik. Perbedaan lainnya dengan SEMA yang lama ialah cara penyertaan dokumen melalui fitur komunikasi data (menu upaya hukum) pada direktori putusan Mahkamah Agung karena cara lama melalui compact disk dan pengiriman e-dokumen memiliki sejumlah kendala diantaranya data tidak terbaca, perangkat penyimpan data hilang dan lain-lain.

Kesimpulannya, SEMA tersebut mengakui dokumen elektronik untuk kelengkapan Permohonan Kasasi dan Peninjauan Kembali, bukan untuk alat bukti persidangan dan penyerahan dokumen oleh pengadilan tingkat pertama dilakukan melalui fitur komunikasi 
data dan tidak melalui perangkat flash disk/compact disk kecuali dalam keadaan khusus. Namun, bagaimana cara penyerahan dokumen elektronik sebagai alat bukti yang sah dipersidangan. Disinilah terdapat kekosongan hukum acara, karena dalam UndangUndang Informasi dan Transaksi Elektronik maupun Undang-Undang lainnya tidak mengatur mengenai tata cara penyerahannya di persidangan.

Kalau dalam praktiknya ada yang menyerahkan melalui compact disk atau flash disk maka sesuai SEMA 1/2014 dijelaskan bahwa hal tersebut menyebabkan sejumlah kendala namun apabila dikirim melalui e-dokumen juga belum diatur tata cara pengirimannya. Tata cara penyerahan menjadi penting karena menyangkut sah atau tidaknya hukum acara perdata yang diterapkan dan dalam rangka memenuhi unsur "dijamin keutuhannya" pada Pasal 6 Undang-Undang ITE. Dijamin keutuhannya berarti tidak diubah-ubah bentuknya sejak dari dokumen elektronik tersebut disahkan.

Dalam hal dokumen elektronik telah diserahkan dipersidangan menurut tata cara yang diterima semua pihak berperkara, maka apabila pihak lawan ingin melihat dokumen elektronik yang akan diajukan sebagai alat bukti tersebut. Ketentuan Pasal 137 HIR mengatur bahwa "Pihak-pihak dapat menuntut melihat surat-surat keterangan lawannya dan sebaliknya, surat mana diserahkan kepada hakim buat keperluan itu".

Dalam menjaga asas keterbukaan pembuktian dipersidangan maka ketentuan 137 HIR juga harus dapat diterapkan pada dokumen elektronik ketika pihak lawan meminta untuk diperlihatkan. Untuk itu, diperlukan perangkat teknologi berupa laptop maupun proyektor agar dapat menampilkan/memperlihatkan dokumen elektronik dan inipun tidak diatur.

Selain itu, dokumen elektronik yang di dalamnya memuat tanda tangan elektronik wajib memenuhi sejumlah kriteria di dalam Pasal 11 Undang-Undang Informasi dan Transaksi Elektronik sehingga memiliki kekuatan hukum dan akibat hukum yang sah. Butir-butir kriteria di atas juga mengandung aspek keamanan dokumen elektronik sebagaimana yang diamanatkan pada Pasal 12 ayat 1 pada Undang-Undang Informasi dan Transaksi Elektronik, diantaranya keaslian (authentication), keutuhan (integrity), dan anti penyangkalan (non repudiation). Berikut pembagian kriteria dalam Pasal 11 UndangUndang Informasi dan Transaksi Elektronik dan aspek jaminan keamanan dalam Pasal 12 Undang-Undang Informasi dan Transaksi Elektronik:

a. Data pembuatan tanda tangan elektronik terkait hanya kepada Penanda Tangan (Keaslian/Authentication)

b. Data pembuatan tanda tangan elektronik pada saat proses penandatanganan elektronik hanya berada dalam kuasa penanda tangan (Keaslian/Authentication)

c. Segala perubahan terhadap tanda tangan elektronik yang terjadi setelah waktu penandatanganan dapat diketahui (Keutuhan/Integrity)

d. Segala perubahan terhadap informasi elektronik yang terkait dengan tanda tangan elektronik tersebut setelah waktu penandatanganan dapat diketahui (Keutuhan/Integrity)

e. Terdapat cara tertentu yang dipakai untuk mengidentifikasi siapa Penandatangannya (Anti Penyangkalan/Non Repudiation) 
Trio Yusandy

f. Terdapat cara tertentu untuk menunjukkan bahwa penanda tangan telah memberikan persetujuan terhadap informasi elektronik yang terkait (Anti Penyangkalan/Non Repudiation)

Tanda tangan elektronik yang mampu menjamin terpenuhinya butir a dan $\mathrm{f}$ adalah tanda tangan yang tersertifikasi dan dapat "dipertanggung jawabkan" sebagaimana dimaksud dalam Pasal 6 Undang-Undang Informasi dan Transaksi Elektronik. Hal ini karena berfungsi sebagai alat autentikasi dan verifikasi atas identitas penandatangan, keutuhan dan keautentikan informasi elektronik serta dibuat dengan menggunakan jasa penyelenggara sertifikasi elektronik sebagaimana dimaksud Pasal 54 Peraturan Pemerintah Nomor 82 Tahun 2012 tentang Penyelenggaraan Sistem dan Transaksi Elektronik.

Salah satu penyelenggara sertifikat digital atau elektronik, yang berisi tanda tangan digital dan identitas diri pemilik sertifikat yang telah berjalan adalah Badan Siber dan Sandi Negara (BSSN) yang dapat melayani keperluan lembaga pemerintah maupun selain pemerintah. Untuk memastikan standarisasi jasa penyelenggara sertifikasi elektronik, Kementerian Komunikasi dan Informasi sedang menyusun regulasinya.

Pengakuan lainnya terhadap dokumen elektronik semakin tegas dimuat pada Peraturan Mahkamah Agung (PERMA) Nomor 3 Tahun 2018 tentang Administrasi Perkara di Pengadilan Secara Elektronik. Dalam ketentuan Pasal 17 PERMA tersebut diatur bahwa "Pengadilan menerbitkan salinan putusan/penetapan secara elektronik. Salinan putusan/penetapan Pengadilan yang diterbitkan secara elektronik dikirim kepada para pihak paling lambat 14 (empat belas) Hari sejak putusan/penetapan kecuali kepailitan/PKPU", pengiriman dilakukan melalui domisili elektronik. Namun sesuai dengan ketentuan Pasal 23 ayat (3) Keputusan Direktur Jenderal Badan Peradilan Umum Nomor 271/DJU/SK/PS01/4/2018 diatur bahwa "salinan putusan /penetapan tidak dapat digunakan sebagai alat bukti yang sah". Hal ini berarti, Peradilan Umum khususnya tetap wajib mengeluarkan putusan/penetapan dalam bentuk cetak yang dapat dipergunakan sebagai alat bukti.

Salinan putusan dalam bentuk dokumen elektronik, kelak dapat ditandatangani secara elektronik apabila telah tersertifikasi dan terhadap salinan dokumen putusan yang demikian tidak perlu dicocokkan dengan aslinya sebagaimana alat bukti surat menurut Pasal 1888 KUHPerdata. Sesuai dengan maksud Penjelasan Pasal 6 Undang-Undang Informasi dan Transaksi Elektronik maka "Keaslian putusan dalam bentuk dokumen elektronik dengan putusan asli yang ditandantangani oleh Majelis Hakim tidak perlu dibandingkan karena dalam lingkup sistem elektronik, informasi yang asli dengan salinannya tidak relevan lagi untuk dibedakan sebab Sistem Elektronik pada dasarnya beroperasi dengan cara penggandaan yang mengakibatkan informasi yang asli tidak dapat dibedakan lagi dari salinannya".

Berkembangnya penggunaan sarana elektronik dalam berbagai transaksi, di samping memberikan manfaat yang positif yakni adanya kemudahan bertransaksi, juga memberikan manfaat yang sangat besar bagi penyimpanan dokumen sebagai hasil kegiatan usaha yang dilakukan. Namun, memang diakui bahwa disamping keuntungan tersebut dalam penggunaan sarana elektronik terdapat pula kekurangan atau kelemahannya apabila dihadapkan pada masalah alat bukti di pengadilan. 
Penerapan Undang-Undang Informasi dan Transaksi Elektronik ternyata sampai dengan saat ini tidak dapat diterapkan $100 \%$ sesuai dengan undang-undang tersebut, hambatan-hambatan penerapan Undang-Undang Informasi dan Transaksi Elektronik tetap saja ada dalam praktik di lapangan. Hambatan tersebut datang dari itu sendiri yaitu pada substansi Undang-Undang Informasi dan Transaksi Elektronik hambatan hukum di luar Undang-Undang Informasi dan Transaksi Elektronik, hambatan teknologi, hambatan sosial dan kultural, hambatan stabilitas finansial dan keamanan, hambatan pemahaman Undang-Undang Informasi dan Transaksi Elektronik oleh aparat penegak hukum.

\section{Upaya yang dapat dilakukan dalam menguatkan kekuaatan alat bukti elektronik}

Pelaksanaan sistem pembayaran internet sangat dimungkinkan munculnya sengeketa para pihak yang terkait dalam sistem pembayaran. Oleh karena itu, penting sekali dilakukan upaya-upaya penyelesaian sengketa, lebih khusus lagi penyelesaian sengketa ini juga dapat dijadikan sebagai instrumen perlindungan bagi nasabah yang melakukan transaksi pembayaran melalui media internet.

Persoalan hukum muncul ketika sengeketa dalam sistem pembayaran internet berbenturan dengan isu yurisdiksi hukum. Namun, dalam jangka waktu pendek, penggunaan model penyelesaian hukum nonpenal tradisional masih sangat memungkinkan. Lembaga hukum yang dapat digunakan untuk penyelesaian sengketa dalam transaksi pembayaran internet melalui lembaga Alternative Dispute Resolution (ADR), Abdulkadir Muhammad 2012:23).

Dalam sudut pandang yang luas, Alternative Dispute Resolution (ADR). meliputi segala cara penyelesaian sengketa di luar pengadilan, dan secara garis besar, Alternative Dispute Resolution (ADR). dapat diklasifikasikan ke dalam negosiasi, good offices, mediasi, konsiliasi, arbitrase, dan kombinasi dari kelima media tersebut minitrial, summary jurytrial, rent-a-judge, med-arb. Penyelesaian sengketa dalam transaksi pembayaran internet ini dapat saja dilakukan secara tradisional, misalnya melalui lembaga arbitrase. Untuk dapat dilakukan penyelesaian melalui lembaga arbitrase, para pihak harus melihat apakah ada klausul arbitrase. Dalam arti kata selain ada perjanjian pokok yang bersangkutan diikuti atau dilengkapi dengan persetujuan arbitrase. Dari berbagai sumber undang-undang, peraturan dan konvensi internasional dapat dijumpai dua bentuk klausul arbitrase.

Iman Sjahputra (2002:45) mengungkapkan klausul arbitrase yang dimaksud adalah Pactum de compromittendo dan Akta komromis. Pactum de compromittendo adalah para pihak yang mengikatkan kesepatan akan menyelesaikan persengketaan yang munkin timbul melalui forum arbitrase. Pada saat mereka mengikatkan dan menyetujui kalusul arbitrase, sama sekali belum terjadi perselisihan. Pengaturan klausul arbitrase ini ada dalam Pasal 615 Rv serta diatur juga dalam pasal II Konvensi New York 1958.

Dalam Pasal 615 ayat (1) menguraikan: "adalah diperkenankan kepada siapa saja, yang terlibat dalam suatu sengketa yang mengenai hak-hak yang berada dalam kekuasaannya untuk melepaskannya, untuk menyerahkan pemutusan sengketa tersebut kepada seseorang atau beberapa orang wasit." 
Trio Yusandy

Selanjutnya dalam ayat (3) Pasal 615 Reglement op de Burgerlijke Rechsvordering (Rv) ditentukan : "diperkenankan mengikatkan diri datu dengan lain, untuk menyeahkan sengketa- sengketa yang mungkin timbul di kemudian hari, kepada pemutusan seorang atau beberapa orang wasit"

Dari ketentuan Reglement op de Burgerlijke Rechsvordering (Rv) tersebut jelas bagi kita bahwa setiap orang atau pihak yang bersengketa berhak untuk menyerahkan penyelesaian sengketa mereka kepada orang atau beberapa arbiter, yang akan memutuskan sengketa mereka tersebut menurut asas-asas dan ketentuan-ketentuan yang dikehendaki oleh para pihak untuk melakukan penunjukan itu setelah ataupun sengketa terbit, Abdulkadir Muhammad (2012:18).

Penunjukan penyelesaian sengketa lewat arbitrase sebelum sengketa terbit dilakukan dengan pencantuman klausula arbitrasi dalam perjanjian pokok mereka. Sedangkan petunjuk arbitrase sebagai cara penyelesaian sengketa setelah sengketa terbit dilakukan dengan membuat persetujuan arbitrase sendiri.

Tata cara pembuatan klausul Pactum de compromittendo ini dapat dilakukan dengan dua cara, yaitu :

1. Mencantumkan klausul arbitrase yang bersangkutan dalam perjanjian pokok;

2. Pactum de compromittendo dibuat dalam akta tersendiri. Perjanjian arbitrase dalam hal ini tidak langsung digabung menjadi satu dengan perjanjian pokok.

Muhammad Nur Al-Azhar (2012:44) menyebutkan bahwa sesudah dikeluarkannya Undang-Undang No. 30 Tahun 1999 tentang Arbitrase dan Alternatif Penyelesaian Sengketa, pengakuan hukum Indonesia terhadap putusan arbitrase asing semakin kuat. Hal itu dibuktikan dengan pengaturan hukum mengenai arbitrase internasional yang diatur dalam bagian kedua, Pasal 65 sampai dengan Pasal 69. Secara otomatis pula Keppres No. 31 Tahun 1981 dan Permen No. 1 Tahun 1990 menjadi tidak berlaku. Pada perkembangannya, mekanisme penyelesaian sengketa dengan Alternative Dispute Resolution (ADR). yang biasanya digunakan dalam sengketa bisnis yang berbasis kertas (tradisional) dapat diperluas dengan transaksi online. Kalau terjadi sengketa, maka dapat diselesaikan dengan online. Hal ini dapat mengurangi waktu dan biaya Alternative Dispute Resolution (ADR).. Istilah dari model penyelesaian semacam ini sedring disebut dengan Alternative Dispute Resolution (ADR) online, Muhammad Nur Al-Azhar (2012:34).

Pendekatan baru ini dibangun dan disediakan agar lebih fleksibel, tepat waktu, dan mekanisme yang efisien sekaligus menekan biaya yang harus dikeluarkan. Model ini dikembangkan dengan maksud untuk membangun sistem yang dapat memuaskan nasabah, yang penyelesaiannya dapat diselesaikan setiap saat. Model Alternative Dispute Resolution (ADR). online yang dikembangkan sekarang ini banyak mengambil bentuk mediasi. Pertimbangan dengan model mediasi adalah penyelesaian hukum dapat dilaksankan dengan lebih tepat waktu serta dimungkinkan adanya efisiensi biaya. Namun demikian, bukan verarti bentuk-bentuk Alternative Dispute Resolution (ADR) lain tidak dapat digunakan, sesungguhnya bentuk lain pun sebenarnya sama saja.

Supomo (1983:44), menyatakan Jika sengketa terjadi antara warga negara atau penduduk Indonesia dengan situs belanja online yang berada di Indonesia, tidak akan masalah dikarenakan adanya Undang-Undang Perlindungan Konsumen berlaku dan 
mengikat mereka. Bahkan dalam ketentuan umum Lipposhop ditegaskan bahwa "layanan yang dibuat oleh Lipposhop dengan berpegang teguh pada Undang-Undang No. 8 Tahun 1999 tentang Perlindungan Konsumen". Ini berarti perlindungan hukum perlindungan konsumen berlaku penuh dalam transaksi yang dilakukan konsumen dengan Lipposhop. Meskipun Undang-Undang Perlindungan Konsumen belum menjangkau $e$ commerce secara keseluruhan, tetapi untuk perusahaan yang jelas alamat dan keberadaannya, jika perusahaan tersebut melakukan wanprestasi, ia dapat dituntut secara hukum. adalah :

Upaya yang dapat dilakukan agar menguatkan pembuktian alat bukti elektronik

1. Dapat Menampilkan Informasi Elektronik atau Dokumen Elektronik Secara Utuh Dengan Syarat Sesuai Dengan Perundang-undangan

Bukti elektronik yang dipakai oleh pihak-pihak yang bersengketa haruslah sesuai perundang-undangan, seperti yang telah dijelaskan Pasal 5 ayat (3) informasi elektronik dan/atau dokumen elektronik dinyatakan sah apabila menggunakan sistem elektronik sesuai dengan ketentuan yang diatur dalam undang-undang ini.

2. Dapat Menjamin Keaslian Alat Bukti Elektronik

Suatu informasi elektonik dan dokumen elektronik harus berbentuk atau asli agar dianggap sah sepanjang informasi dan dokumen yang tercantum didalamnya dapat diakses, ditampilkan dan dijamin keutuhannya dan dapat di pertanggungjawabkan sehingga menerangkan sesuatu keadaan.

3. Dilengkapi Dengan Petunjuk Yang Umum

Informasi elektronik atau dokumen elektonik dilengkapi dengan penjelasanpenjelasan atau petunjuk umum seperti bahasa atau simbol yang dapat dipahami oleh pihak yang bersangkutan dengan penyelenggaraan sistem elektronik, sehingga dapat meyelesaikan perkara dengan mudah.

4. Memiliki Mekanisme Berkelanjutan

Dengan memiliki mekanisme berkelanjutan akan lebih mudah untuk proses pembuktianya.mekanisme berkelanjutan ini berguna untuk menjaga kebaruan dari sistem-sistem yang semakin berkembang, untuk kejalasan dari sistem pembuktian dan kkebertanggung jawaban petunjuk dalam pembuktian infomasi elektronik dan dokumen elektronik.

\section{KESIMPULAN}

1. Kedudukan alat bukti elektronik berdasarkan Undang-undang Nomor 8 tahun 1997 tentang Dokumen Perusahaan, bahwa dokumen perusahaan adalah data, catatan, atau keterangan yang dibuat dan diterima oleh perusahaan dalam rangka pelaksanaan kegiatannya, baik tertulis di atas kertas. Dan Kekuatan pembuktian yang disetarakan dengan dokumen yang dibuat di atas kertas. Hal ini, berarti bahwa kekuatan pembuktian dokumen elektronik dalam praktik perkara perdata dipersamakan dengan kekuatan alat bukti tulisan (surat).

2. Faktor-faktor penghambat kekuatan dan kedudukan alat bukti elektronik dalam persidangan yaitu adanya hambatan substansi Undang-undang Informasi dan 
Trio Yusandy

Transaksi Elektronik, hambatan hukum diluar dari Undang-undang Informasi dan Transaksi Elektronik, teknologi, sosial budaya dan hambatan dalam pembuktian dimuka persidangan.

3. Upaya yang dapat dilakukan dalam menguatkan kedudukan dan kekuatan alat bukti elektronik dalam sistem pembuktian perkara perdata di Indonesia yaitu dengan menampilkan informasi elektronik atau dokumen elektronik secara utuh dengan syarat yang sesuai, dapat menjamin keaslian alat bukti elektronik, dilengkapi dengan petunjuk yang umum dan memiliki mekanisme yang berkelanjutan.

\section{DAFTAR PUSTAKA}

Abdulkadir Muhammad, Hukum Acara Perdata Indonesia. Cet. IX. Bandung : PT. Citra Aditya Bakti, 2012.

Achmad Ali dan Wiwie Heryani, Asas-asas Hukum Pembuktian Perdata. Jakarta : Prenada Media, 2013.

Achmad Ali, Menguak Teori Hukum (Legal Theory) dan Teori Peradilan (Judicialprudence) : Termasuk Interpretasi Undang-undang (Legisprudence). Edisi I, Cet.III; Jakarta : Kencana, 2009.

Ahmad M. Ramli, Pager Gunung, dan Indra Priadi, Menuju Kepastian Hukum di Bidang: Informasi dan Transaksi Elektronik, Departemen Komunikasi dan Informatika Republik Indonesia. Jakarta, 2005.

-------, Ruang Lingkup Permasalahan Eksekusi Bidang Perdata, Jakarta: Gramedia Pusta Utama 1991.

Iman Sjahputra, Problematika Hukum Internet Indonesia. Cet. I; Jakarta : PT. Prenhallindo, 2002.

M. Natsir Asnawi, Hukum Pembuktian Perkara Perdata di Indonesia : Kajian Kontekstual mengenai Sistem, Asas, Prinsip, Pembebanan dan Standar Pembuktian. Yogyakarta : UII Press, 2013.

Mochtar Kusumaatmaja, Konsep-Konsep Hukum Konsep-Konsep Hukum Dalam Pembangunan. Bandung, Alumni, 2002.

Muhammad Nur Al-Azhar, Digital Forensic, Panduan Praktis Investigasi Komputer. Jakarta: Penerbit Salemba Infotek, 2012.

Riawan Tjandra W., dan H. Chandera., Pengantar Praktis Penanganan Perkara Perdata, Universitas Atma Jaya Jogjakarta, 2001.

Subekti, R, Tjitrosudibuio, R., Kitab Undang - Undang Hukum Perdata, Pradya Paramita, Jakarta, Cet.25, 2009.

Sitompul, Asril., Hukum Internet (Pengenalan Mengenai Masalah Hukum di Cyberspace). Bandung: PT. Citra Aditya Bakti, 2001.

Soekanto S., Pengantar Penelitian Hukum. UI Perss. Jakarta, 2014.

Supomo, Hukum Acara Perdata Pengadilan Negeri. Jakarta: Penerbit Fasco, 1983.

Titik Triwulan Tutik, Hukum Perdata dalam Sistem Hukum Nasional. Cet. III; Jakarta : Kencana, 2011.

Yan Pramadya Puspa, Kamus Hukum. Cet. I; Semarang : Aneka Ilmu, 2008. 